\title{
Displasia Ektodermal Hipohidrotik
}

\author{
Eveline PN, Sri Rezeki Hadinegoro, Siti Aisah Boediardja
}

\begin{abstract}
Seorang bayi laki-laki berusia 4 bulan menderita displasia ektodermal hipohidrotik (DEH), merupakan kelainan genetik yang sebagian besar diturunkan secara $x$-linked recessive. Sindrom ini ditandai dengan tidak ada atau berkurangnya kelenjar keringat, hypotrichosis, dan hypodontia. Diagnosis ditegakkan berdasarkan gejala klinis dan dipastikan dengan biopsi kulit yang menunjukkan tidak ada atau hipoplasi kelenjar ekskrin dan rambut. Trias gambaran klinis utama $\mathrm{DEH}$ adalah hipohidrosis atau anhidrosis, hipotrikosis dan andontia total atau partial. Kelainan ini perlu segera ditegakkan untuk menghindari komplikasi yang berat pada masa bayi dan diperlukan untuk menentukan penanganan selanjutnya. Untuk mengetahui pola penurunan genetik pada pasien ini perlu disusun silsilah penyakit dalam keluarga serta biopsi kulit atau uji starch-iodine pada kedua orang tua pasien sehingga konseling genetik. Pencegahan dapat diberikan secara multidisiplin sangat diperlukan dalam penanganan kasus seperti ini agar mendapatkan prognosis yang lebih baik. Displasia ektodermal hipohidrotik yang disebut juga Christ-Siemens Touraine syndrome atau displasia ektodermal anhidrotik digambarkan pertama kali pada tahun 1848 oleh Thurnam ${ }^{1,2}$ dan diikuti pada abad-19 oleh Darwin. ${ }^{2}$ Pada tahun 1921, Thadani menetapkan DEH sebagai suatu kelainan $x$-linked dan kemudian melaporkan bahwa perempuan pembawa gen mutan menampakkan gejala yang bervariasi dari kondisi tersebut. ${ }^{1,2}$

Angka kejadian DEH diperkirakan 1 per 100.000 kelahiran hidup, ${ }^{2,5}$ lebih $90 \%$ terjadi pada anak laki-laki. ${ }^{2}$ Di Indonesia dilaporkan 2 kasus pada tahun 2000-2002, ${ }^{6}$ salah satu kasus berobat di Subbagian Kulit Anak Ilmu Penyakit Kulit dan Kelamin FKUI-RSCM.7
\end{abstract}

Kata kunci: displasia ektodermal hipohidrotik, anhidrosis, anodontia, hipotrikosis, $x$-linked recessive

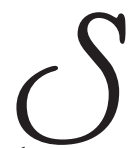

eorang bayi laki-laki, berusia 4 bulan berobat ke RSCM dengan keluhan utama demam sejak 3 bulan yang lalu. Dari aloanamnesis dengan ibu dan nenek didapatkan keterangan sejak 3 bulan yang lalu pasien menderita demam hilang timbul

Dr. Eveline PN, PPDS Ilmu Kesehatan Anak FKUI, Jakarta

Prof. DR. Dr. Siti Aisah, Sp.KK. Subbagian Kulit Anak. Bagian Kulit Kelamin FKUI-RSCM, Jakarta. Telepon: 021-493033.

Alamat korespondensi:

Prof. DR. Dr. Sri Rezeki S Hadinegoro, Sp.A(K).

Subbagian Infeksi dan Penyakit Tropis. Bagian Ilmu Kesehatan Anak FKUI-RSCM, Jakarta.

Jl. Salemba no. 6, Jakarta 10430.

Telepon: 021-391 4126, Fax.: 021-390 7743 . dan tidak terlalu tinggi. Demam terjadi terutama di ruangan dengan hawa panas, demam kadang-kadang turun setelah minum obat penurun panas. Jika pasien di ruangan dingin, suhu tubuhnya kembali normal. Pasien sering bersin-bersin dan hidung tersumbat sehingga pasien terlihat sulit bernapas.

Sekitar dua bulan yang lalu dari telinga pasien keluar cairan jernih dan berbau. Dokter spesialis THT mengatakan pasien menderita otitis media akut dan dilakukan timpanosintesis. Namun setelah dua kali dilakukan timpanosintesis dan pemberian antibiotik, keluhan telinga hilang Namun pasien tetap demam.

Orang tua pasien mengatakan bahwa sejak anak lahir tidak pernah berkeringat dan rambut kepala tidak tumbuh. 
Dari riwayat keluarga, didapatkan paman pasien (kakak dari ibu pasien) tidak berambut seperti pasien dan meninggal dunia ketika berumur 1 bulan oleh karena demam terus menerus dan kejang (Gambar 1).

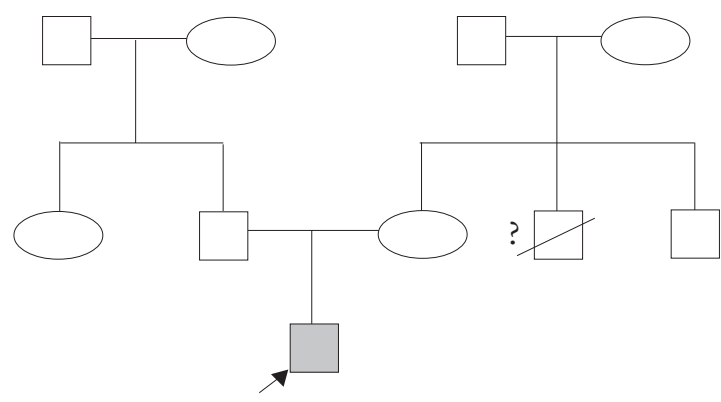

Gambar 1. Peta silsilah keluarga pasien Keterangan
Laki-laki

\section{Perempuan}

Pada pemeriksaan fisis didapatkan bayi laki-laki dengan berat badan $5,8 \mathrm{~kg}\left(\mathrm{P}_{10-25} \mathrm{NCHS}\right)$, panjang badan $63 \mathrm{~cm}\left(\mathrm{P}_{50} \mathrm{NCHS}\right), \mathrm{BB} / \mathrm{U} 93 \%$; TB/U 100\% ; $\mathrm{BB} / \mathrm{TB}$ 93\%. Pasien sadar, tidak sesak maupun sianosis. Laju nadi sama dengan laju jantung 120 kali permenit, laju pernapasan 32 kali per menit, suhu aksila $38^{\circ} \mathrm{C}$. Kulit kering agak bersisik dan tidak berkeringat.

\section{(Gambar 2)}

Pada pemeriksaan kepala didapatkan lingkar kepala $42 \mathrm{~cm}$ (normal), ubun-ubun besar datar, kulit kepala kering, erosi dan skuamasi, rambut kepala halus, tipis dan jarang, tidak ada alis dan bulu mata. Wajah tampak

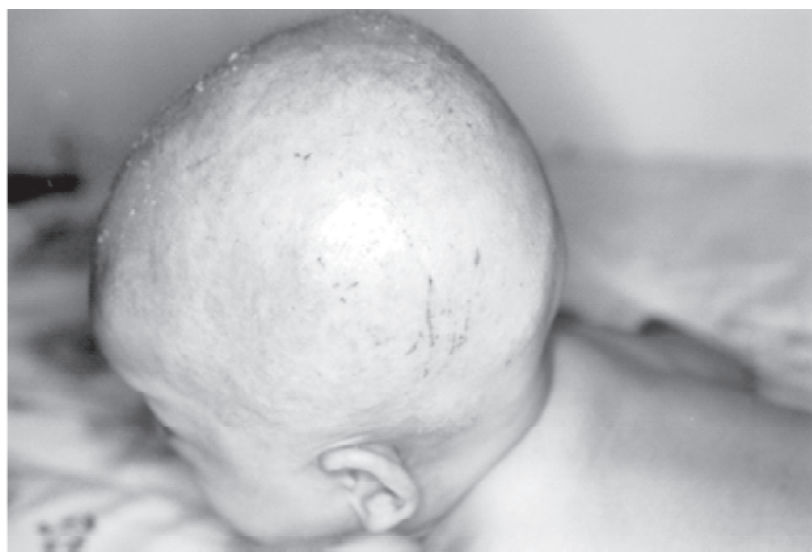

Gambar 2. Kulit kepala pasien DEH tampak kering dan bersisik dismorfik, dahi besar dan menonjol, tulang hidung datar, bibir tebal dan dagu lancip(Gambar 3).

Konjungtiva tidak pucat, sklera tidak ikterik, gerakan bola mata baik, terdapat hiperpigmentasi periorbital dan keriput di sekitar mata. Pada kedua telinga didapatkan serumen, pada hidung tidak terdapat sekret, tonsil T1 - T1 faring tidak hiperemis. Gigi belum tumbuh. Pada leher tidak ditemukan pembesaran kelenjar getah bening. Bunyi jantung I dan II normal, tidak terdengar bising jantung maupun irama derap. Suara napas vesikular, tidak terdapat ronki maupun mengi. Perut datar, lemas, turgor cukup, tidak teraba hati dan limpa, bising usus normal. Akral hangat, perfusi perifer baik, refleks fisiologis normal, tidak terdapat refleks patologis ataupun kelumpuhan. Pada lipatan siku kanan terdapat kelainan kulit berupa eritema berbatas tegas dan skuama. Parut BCG tampak pada deltoid kiri. Kuku kaki dan tangan normal.

Pemeriksaaan darah tepi menunjukkan hemoglobin $10,4 \mathrm{~g} / \mathrm{dL}$, hematokrit 28,9 vol\%, leukosit $13.100 / \mu \mathrm{L}$, trombosit $400.000 / \mu \mathrm{L}$, hitung jenis (\%): basofil 0, eosinofil 0, batang 1, segmen 34, limfosit 64 dan monosit 1. Laju endap darah $10 \mathrm{~mm} / 1$ jam. Urinalisis dan pemeriksaan feses rutin dalam batas normal. Uji tuberkulin didapatkan indurasi diameter

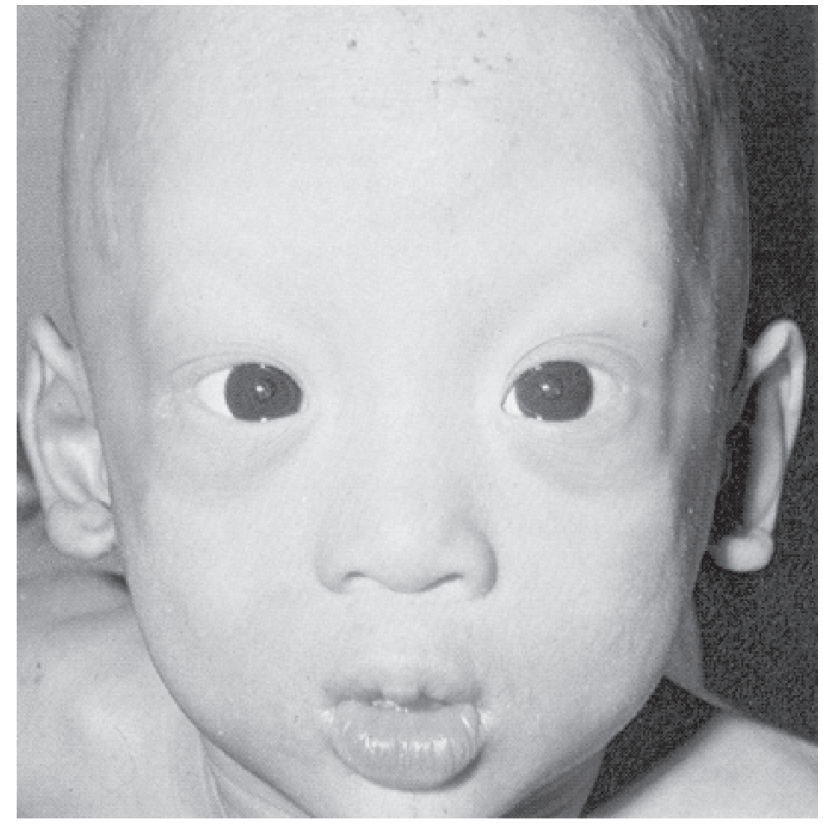

Gambar 3. Wajah pasien DEH tampak dismorfik dahi besar dan menonjol, tulang hidung datar, bibir tebal dan dagu lancip 
$15 \mathrm{~mm}$. Biakan darah dan urin steril. Pemeriksaan imunoglobulin ialah IgG 562,3 mg/dl, IgA 27,9 mg/ dl, IgM 50,8 mg/dl, dan IgE 339,3 IU/ml.

Pemeriksaan foto toraks menunjukkan infiltrat ringan pada paru danpembesaran kelenjar timus. Pemeriksaan ultrasonografi abdomen dalam batas normal. Pada foto sinus paranasalis tidak terlihat perselubungan. Pada CT scan kepala tampak tandatanda atrofi serebral minimal. Dari hasil konsultasi ke Bagian Kulit, anak diduga menderita DEH maka dilakukan biopsi kulit palmar didapatkan epidemis hiperkeratosis/parakeratosis dan tidak tampak adanya kelenjar ekrin di lapisan dermis(Gambar 4). Kelainan ini sesuai dengan displasia ektodermal anhidrotik. Untuk perawatan kulit pasien diberikan pelembab yaitu asam laktat 5\% dan mandi dengan sabun oilum. Tidak terdapat kelainan THT dan tidak didapatkan tanda-tanda otitis media akut. Hasil konsultasi ke Bagian Mata tidak didapatkan kelainan pada mata.

Berdasarkan pemeriksaan laboratorium dan penunjang serta konsultasi ahli terkait maka ditegakkan diagnosis displasia ektodermal hipohidrotik dan infeksi tuberkulosis paru. Diberikan pengobatan INH 1x50 mg, sedangkan antibiotik dihentikan setelah 7 hari. Pasien dipulangkan setelah dirawat dua belas hari

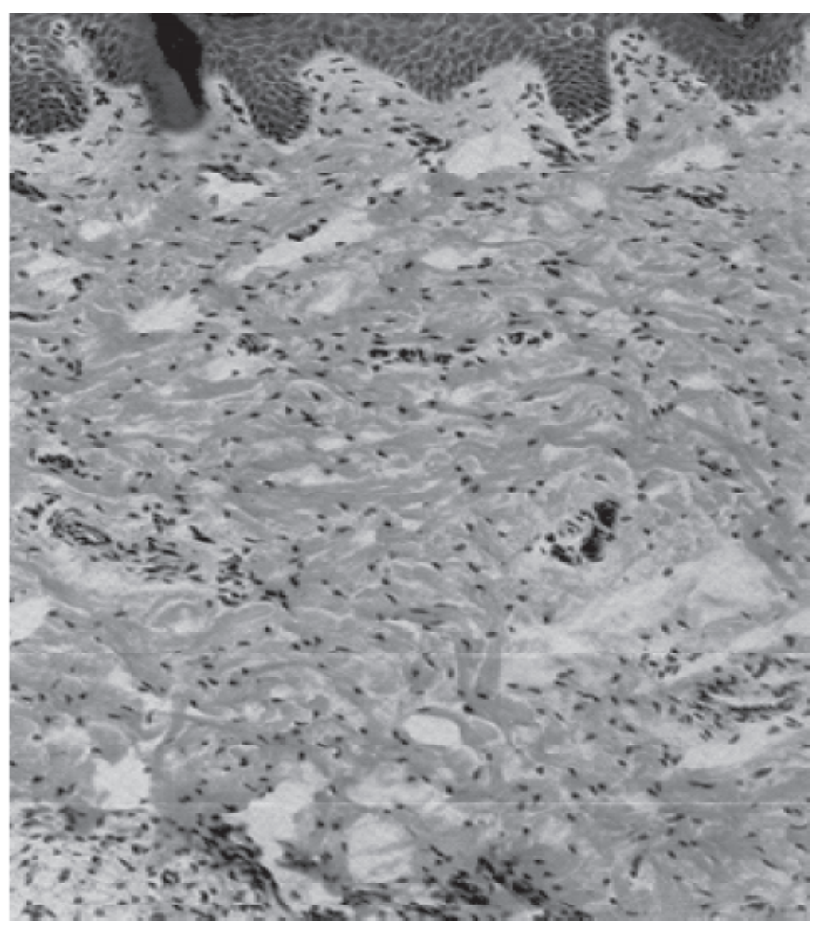

Gambar 4. Gambaran histopatologi menunjukkan hiperkeratosis/ parakeratosis lapisan epidermis kulit dalam keadaan baik dengan nasehat menghindari lingkungan panas dan minum lebih sering agar regulasi suhu tubuh teratur dan perlu tindak lanjut pada dokter spesialis anak, mata, dan kulit.

\section{Diskusi}

Displasia ektodermal hipohidrotik merupakan salah satu sindrom yang tersering dalam kelompok besar displasia ektodermal (DE). Displasia ektodermal adalah kelompok kelainan genetik yang ditandai dengan tidak ada atau kurangnya fungsi dua atau lebih jaringan derivat ektoderm yaitu rambut, gigi, kuku, kelenjar keringat dan struktur ektodermal lain. ${ }^{1,5,8}$ Pinheiro dan Freire-Maia membagi DE berdasarkan derivat ektodermal yang terlibat, terdapat lebih dari 150 jenis yang telah diidentifikasi. ${ }^{2,8}$

Sindrom DEH diturunkan sebagian besar secara $X$ linked recessive tetapi dapat juga autosomal resesif, 1,3 secara klinis kedua bentuk ini sulit dibedakan. ${ }^{1,2}$ Pada pola autosomal resesif penyakit akan terekspresi pada perempuan dan laki-laki, ${ }^{1,3}$ namun tidak muncul pada setiap generasi dan akan muncul pada keadaan homozigot. Risiko sakit akan meningkat bila terjadi konsanguinitas. ${ }^{9}$ Gen yang bertanggung jawab pada $\mathrm{DEH}$ autosomal terpeta pada kromosom 2q11 - q13. ${ }^{10}$ Kelainan $x$-linked recessive dapat terekspresi bila tidak ada kromosom $X$ yang sehat oleh karena itu yang sakit umumnya lebih banyak laki-laki, sedangkan perempuan merupakan pembawa gen mutan. ${ }^{9}$ Pada DEH $x$-linked recessive kelainan pada gen $\mathrm{ED} 1$ yang terletak pada kromosom x regio q12 - q13.1.11

Kelainan yang terjadi pada DEH adalah lapisan epidermis tipis dan rete ridges mendatar. Kelenjar dan saluran keringat ekrin tidak ada atau rudimenter. Jumlah folikel rambut dan kelenjar sebasea menurun bervariasi. Kelenjar apokrin tidak ada, sedikit atau normal. ${ }^{1,2}$ Jaringan konektif dermis biasanya terlihat normal tetapi serabut kolagen dan elastin terpotongpotong atau sedikit. ${ }^{2}$ Mukosa hidung hampir tidak ada sel silia. ${ }^{1}$ Kelenjar mukosa traktus respiratorius atas dan bronkus tidak ada atau sedikit. ${ }^{1,2}$ Kelenjar saliva berkurang atau tidak ada. Kelenjar mukosa duodenum mungkin tidak ada. ${ }^{1}$ Pada pemeriksaan helai rambut dengan mikroskop elektron didapatkan kelainan bervariasi termasuk adanya celah atau alur longitudinal dan transversal, serta atrofi bulbus. ${ }^{1}$ Foto mandibula menunjukkan ada hipoplasi atau aplasi gigi. Respons 
imun dapat tertekan dan kadar Ig E serum meningkat mirip keadaan atopi. ${ }^{2}$

Gambaran klinis utama DEH adalah suatu trias dari hipohidrosis atau anhidrosis, hipotrikosis dan anodontia total atau parsial., ${ }^{2,3}$ Gejala yang muncul pada tahun pertama kehidupan adalah demam yang menetap dan tidak diketahui sebabnya sekunder terhadap ketidakmampuan berkeringat. ${ }^{2,3,12}$ Intoleransi panas terjadi juga pada anak besar, tetapi mereka dapat belajar mengatur suhu tubuh mereka dengan minum cairan dingin, membasahi kulit dan baju mereka serta mencari tempat sejuk. ${ }^{1,12,13}$

Pada tahun kedua ciri khas pada muka menjadi nyata, yaitu dahi menonjol, tulang hidung datar dan maksila yang rata. ${ }^{3}$ Rambut kepala sedikit, halus, sedikit berpigmen dan tumbuh lambat. Alis mata jarang atau tidak ada, bulu mata bisa normal, jarang atau sama sekali tidak ada. Rambut ciri seksual sekunder di daerah dagu, pubis dan aksila bervariasi sedangkan di badan dan ekstremitas biasanya tidak ada. ${ }^{1,2}$

Kelainan gigi bervariasi dalam jumlah dan bentuk gigi abnormal. Gigi susu dan gigi permanen bisa tidak tumbuh atau hanya tumbuh beberapa. Bentuk gigi seri dan atau taring seperti baji. ${ }^{1-3,12}$ Pertumbuhan gigi biasanya terlambat dan cenderung berukuran kecil dan jarak antar gigi lebar. ${ }^{1,3}$ Alveolar ridges hipoplasi sehingga menyebabkan bibir terlihat menonjol. ${ }^{1,12}$ Karies gigi dan maloklusi sering manjadi masalah. ${ }^{12}$

Kuku biasanya normal tetapi pada beberapa individu terlihat tipis, rapuh dan membentuk longitudinal ridges. ${ }^{1-3,10}$ Kulit tampak bersisik pada saat lahir, ${ }^{1,12}$ maka adanya kulit yang bersisik atau terkelupas pada bayi baru lahir yang tidak sesuai dengan usia kehamilan terutama bayi laki-laki, haruslah diperiksa kemungkinan DEH. ${ }^{12,14}$ Kulit pada anak dan dewasa tipis, halus dan kering. Hiperpigmentasi periorbital dan keriput sekitar mata merupakan ciri khas kelainan ini. ${ }^{1,3,12}$ Dermatitis atopik sering terlihat terutama pada daerah fleksura. ${ }^{1,3,12}$

Berkurang atau tidak adanya kelenjar mukosa pada saluran aerodigestivus menimbulkan gangguan fungsi membran mukosa kavum nasi, sinus paranasalis, tuba eustakius, kavum oral, nasofaring, orofaring dan hipofaring, laring dan cabang trakeobronkial. Pada telinga biasanya terjadi cerumen impaction, otitis media kronik atau otitis media berulang. Gangguan hidung berupa obstruksi kronik karena kotoran hidung yang tebal, menempel dan berbau. Tidak efektifnya mukosilia menyebabkan mukus statis sehingga terjadi infeksi sinus paranasalis dan epistaksis. ${ }^{15}$

Produksi saliva yang sedikit menyebabkan gangguan di mulut dan faring, antara lain gangguan mengunyah dan menelan. Kombinasi kelainan pada gigi dan produksi saliva yang kurang akan mempengaruhi pertumbuhan badan, artikulasi dan penampilan. Suara parau terjadi pada laringitis kronik karena kurangnya lubrikasi pada pita suara. Mukus yang tebal menyebabkan pneumonia berulang. ${ }^{15}$ Disfagia, refluks gastroesofagus dan konstipasi dapat terjadi karena berkurang atau tidak adanya kelenjar mukosa di esofagus, gaster dan kolon. ${ }^{1}$ Produksi air mata yang berkurang dapat menyebabkan mata kering, fotofobia, kerusakan kornea, ${ }^{1,3}$ dan kelainan lain berupa katarak. ${ }^{2,3}$ Kelenjar mamae tampak aplasi atau hipoplasi disertai puting susu rudimenter. ${ }^{1-3}$ Retardasi mental terdapat pada $30-50 \%$ kasus, Daniel $\mathrm{dkk}^{15}$ mendapatkan 2 dari 4 pasien $\mathrm{DEH}$ mengalami retardasi mental.

Pasien pada kasus ini datang dengan keluhan utama demam yang berkepanjangan dan tidak diketahui sebabnya. Otitis media akut yang pada awalnya diduga sebagai penyebab demam, maka dilakukan timpanosentesis dua kali namun keluhan demam masih ada. Diagnosis kerja DEH pada pasien ini ditegakkan berdasarkan anamnesis tidak adanya keringat sejak lahir, timbulnya demam terutama jika pasien berada di lingkungan panas dan pertumbuhan rambut yang tipis dan sangat lambat, riwayat otitis media berulang, hidung tersumbat serta didukung pemeriksaan fisis adanya dismorfik pada muka, kulit yang kering tidak berkeringat dan adanya dermatitis atopik.

Diagnosis pasti ditegakkan dengan biopsi kulit atau uji keringat. ${ }^{2}$ Dari pemeriksaan histopatologi kulit, pada DEH didapatkan kelenjar ekrin hipoplasia atau sama sekali tidak ada, disertai hipoplasia rambut dan kelenjar sebasea. ${ }^{16}$ Uji keringat yaitu starch-iodine test digunakan untuk memeriksa distribusi kelenjar keringat yang aktif. Pada kasus ini dilakukan biopsi kulit pada telapak tangan dan didapatkan hasil sesuai $\mathrm{DEH}$.

Gagal tumbuh dapat terjadi pada 40\% kasus lakilaki. Angka kematian pada bayi dan anak kecil sebesar $25 \%$ terutama karena hipertermia, gagal tumbuh dan infeksi respiratori. ${ }^{9}$ Kejang demam dapat terjadi pada hiperpireksia. Masalah bicara dapat terjadi karena hipodontia, obstruksi nasal dan impacted cerumen. ${ }^{1}$

Pendekatan multidisiplin dalam tata laksana pasien 
DEH sangat diperlukan. Diagnosis dini sangat penting untuk mencegah komplikasi yang mengancam jiwa pada bayi, untuk merencanakan tata laksana jangka panjang dan untuk mengetahui adanya faktor risiko dalam keluarga. ${ }^{1}$

Pencegahan hipertermia sangat penting, dengan menghindari lingkungan panas dan kerja fisik yang berlebihan, mendinginkan badan dengan pakaian basah dan minum cairan dingin serta menjaga suhu lingkungan yang sejuk baik di rumah maupun di sekolah. ${ }^{1}$ Intervensi dini yang teratur terhadap pertumbuhan gigi sangat penting untuk artikulasi, pertumbuhan dan penampilan. Anak diajarkan pentingnya menjaga kebersihan gigi untuk mencegah karies dan tanggalnya gigi yang ada, ${ }^{12,15}$ jika perlu dilakukan implan gigi. ${ }^{1}$

Cerumen impaction dapat diatasi dengan irigasi larutan $\mathrm{H}_{2} \mathrm{O}_{2}$ atau cairan lubrikasi (gliserin, minyak mineral). Otitis media serosa kronik yang terjadi karena kelenjar mukosa aplasi atau hipoplasi sehingga terjadi gangguan fungsi tuba eustakius, diobati dengan timpanostomi. Pemeriksaan audiometri dianjurkan untuk mendeteksi gangguan pendengaran. ${ }^{15}$ Humidifikasi penting dalam tatalaksana gejala pada hidung. Antibiotik digunakan pada keadaan infeksi. Pengangkatan krusta di hidung dilakukan secara hati-hati jika diperlukan, terutama pada bayi yang bernafas dengan hidung. ${ }^{15}$ Keluhan sumbatan dapat diatasi dengan pemberian tetes hidung $\mathrm{NaCl} .{ }^{1}$ Kebutuhan cairan dalam jumlah banyak atau preparat saliva buatan dapat mengurangi kekeringan mulut dan kesulitan menelan. Mata yang kering dapat diobati dengan air mata buatan. ${ }^{1,12}$

Masalah paru dapat diatasi dengan mencegah paparan asap rokok, lingkungan berdebu, kelembaban yang cukup dan melakukan fisioterapi dada serta antibiotik jika diperlukan. ${ }^{1,15}$ Kulit dirawat dengan memberikan pelembab yang sesuai untuk perawatan kulit kering. ${ }^{3}$ Pada pasien dengan distrofi kuku kadang diperlukan sepatu khusus. Alopesia diatasi dengan memakai model potongan rambut yang sesuai atau protesa rambut sesuai dengan usia. ${ }^{12}$

Pada kasus ini pasien telah ditangani secara multidisiplin. Orangtua diberikan edukasi untuk tetap menjaga suhu badan pasien normal, dan cara mengatasi jika suhu meningkat. Untuk perawatan kulit diberikan asam laktat 5\%. Pasien dianjurkan berobat teratur ke dokter guna melengkapi imunisasi dasar. Untuk mengetahui pola penurunan genetik, perlu disusun silsilah penyakit dalam keluarga melalui pendekatan anamnesis yang teliti serta pemeriksaan fisis atau laboratorium tertentu., ${ }^{9,17,18}$ Clarke $\mathrm{dkk}^{13}$ pada tahun 1987 menyatakan pada $x$ linked recessive perempuan pembawa gen mutan $70 \%$ menderita hipotrikosis, $80 \%$ mempunyai kelainan gigi termasuk tidak adanya gigi permanen dan bentuk gigi seperti baji dan sekitar 25\% mengalami intoleransi panas dan hampir setengah menunjukkan penurunan kemampuan berkeringat. Kira-kira 30\% tidak menunjukkan manifestasi klinis. ${ }^{19}$ Starchiodine test dan biopsi kulit dapat membantu mendeteksi adanya perempuan pembawa gen mutan. ${ }^{11,13}$

Kasus ini adalah seorang anak laki-laki dengan riwayat keluarga diduga pamannya juga menderita DEH. Ibu dan ayah pasien tidak menampakkan gejala klinis dari sindrom ini. Perlu direncanakan pemeriksaan biopsi kulit atau starch-iodine test pada orang tua pasien untuk memperkirakan pola penurunan genetiknya sehingga konseling genetik dapat diberikan. Diagnosis prenatal DEH dapat dilakukan dengan biopsi kulit yang diambil dengan fetuskopi pada fetus laki-laki usia 20 minggu untuk melihat ada tidaknya folikel pilosebasea. Kelenjar keringat ekrin yang mula-mula terbentuk di telapak tangan, telapak kaki dan aksila kemudian di tubuh lainnya pada akhir bulan kelima., ${ }^{3,20}$ Suatu teknik pemeriksaan prenatal indirek yang dilakukan dengan pemeriksaan DNA pada sampel vili korionik pada masa gestasi 10 minggu, dapat menggantikan biopsi kulit fetus karena lebih aman. , $3,20^{2}$

\section{Daftar Pustaka}

1. Francis JS. Ectodermal dysplasias. Dalam: Harper J, Oranje A, Prose N, penyunting. Textbook of pediatric dermatology. London: Blackwell Science, 2000. h.1163-87.

2. Harper JI. Genetic and genodermatoses. Dalam: Champion RH, Burton JL, Burns DA, Breathnach SM, penyunting. Textbook of dermatology. Edisi ke-6. London: Blackwell Science, 1998. h. 357-436.

3 Micali G, Guitart J, Bene-bain MA, Solomon LM. Genodermatoses. Dalam: Schachner LA, Hansen RC, penyunting. Pediatric dermatology. Edisi ke 2 New York: Churchill Livingstone, 1995. h. 347-411.

4. Hypohydrotic (anhidrotic) ectodermal dysplasia. Didapat dari: URL:http//www.icondata.com/health/ pedbase/files/HYPOHIDR.HTM (disitasi tanggal 14 Februari 2003).

5. Duran-McKinster C. Ectodermal dysplasia. eMedicine Journal 2001; 3:1-12. 
6. Data Rekam Medik Subbagian Kulit Anak Ilmu Penyakit Kulit dan Kelamin FKUI.

7. Anastasia A, Boediardja SA, Lestari T, Wardhani T. Displasia ektodermal anhidrotik. MDVI 2001;28/ SI:116S-119S.

8. What is ectodermal dysplasia? Didapat dari: URL:http; lwww.nfed.orglectodermal.htm. (disitasi tanggal 14 Februari 2003).

9. Boediardja SA. Konseling genetik: Prinsip dan metode. Disampaikan pada temu ilmiah dan reuni alumni Bagian Ilmu Penyakit Kulit dan Kelamin FKUI. Jakarta 23-25 Juni 2000. h. 6-12.

10. Odom RB, James WD, Berger TG. Some genodermatoses and acquired syndromes. Dalam: Odom RB, James WD, Berger TG, penyunting. Disease of the skin clinical dermatology. Edisi ke-9. Philadelphia: WB Saunders Company, 2000. h. 682-732.

11. Ectodermal dysplasia 1, anhidrotic; ED1. Didapat dari: URL:http;//www.ncbi.nlm.nih.gov/entrez/query.fcg?cmd = Retrive\& $d b=O M I M \& d o p t=$ Detailed o $t$... (disitasi tanggal 19 Maret 2003)

12. Siverman R. Nail and appendageal abnormalities. Dalam: Schachner LA, Hansen RC, penyunting. Pediatric dermatology. Edisi ke-2. New York: Churchill Livingstone, 1995. h. 615-59.

13. Clarke A, Phillips DIM, Brown R, Harper PS. Clinical aspects of X- linked hypohidroticectodermal dysplasia. Arch Dis Child 1987; 62:989-96.

14. The Executive and Scientific Advisory Boards of the Na- tional Foundation for Ectodermal Dysplasia, Mascoutah, Illinois. Scaling skin in the neonate: a clue to the early diagnosis of X-linked hypohidrotic ectodermal dysplasia (Christ-Siemens-Touraine syndrome). J Pediatr 1989; 114:600-2.

15. Daneil E, McCurdy EA, Shashi V, McGuirt WF. Ectodermal dysplasia: otolaryngologic manifestations and management. Laryngoscope 2002; 112:962-7.

16. Johnson B, Honig P. Congenital disease (Genodermatoses). Dalam: Elder D, Elenitsas R, Jaworsky C, Johnson B, penyunting. Lever's Histopathology of the skin. Edisi ke-8. Philadelphia: Lippincott-Raven, 1997. h. 117-50.

17. Cambiaghi S, Restano L, Paakkonen K, Caputo R, Kere $\mathrm{J}$. Clinical findings in mosaic carriers of hypohidrotic ectodermal dysplasia. Arch Dermatol 2000; 136:217-224.

18. Bartstra HLJ, Hulsmans RFHJ, Steijlen PM, Ruige M, de Die-Smulders CEM, Cassiman J. Mosaic expression of hypohidrotic ectodermal dysplasia in an isolated affected female child. Arch Dermatol 1994; 130:1421-4.

19. Vincent MC, Cossee M, Vabres P, Stewart F, Bonneau D, Calvas P. Pitfalls in clinical diagnosis of female carriers of X-linked hypohidrotic ectodermal dysplasia. Arch Dermatol 2002; 138:1256-8.

20. Haake AR, Holbrook K. The structure and development of skin. Dalam: Freedberg K Eisen AZ, Wolff K, Austen KF, Goldsmith LA, Katz SI et al, penyunting. Fitzpatrick's Dermatology in general medicine. Edisi ke-5. New York: Mc Graw-Hill, 1999. h. 70-114. 